\title{
TPX2 Gene
}

National Cancer Institute

\section{Source}

National Cancer Institute. TPX2 Gene. NCI Thesaurus. Code C116082.

This gene plays a role in the assembly of the mitotic spindle. 